\title{
Role of succession planning and management accounting towards the performance of family-owned businesses with a moderating role of networking orientation
}

\author{
Areeba Suleman ${ }^{1}$, Armanurah Muhammad ${ }^{2}$, Nazlina Zakaria $^{3}$ \\ ${ }^{1}$ School of Business, Universiti Utara Malaysia \\ ${ }^{2}$ Associate Professor, School of Business, Universiti Utara Malaysia \\ ${ }^{3}$ Senior Lecturer, School of Business, Universiti Utara Malaysia \\ 1areebakhan900@gmail.com, ${ }^{2}$ armanurah@uum.edu.my, ${ }^{3}$ nazlina@uum.edu.my
}

\begin{abstract}
The underpinning objective of this current study to test the role of succession planning (structural, cognitive, and relational ties) and management accounting practices towards the performance (financial and non-financial) of family-owned SMEs with moderating role of networking orientation. We surveyed 306 owners/managers of family-owned SMEs from the sports good industry (manufacturing units). The findings show that the impact of succession planning, structural, cognitive and relational ties towards performance is positive and significant. Furthermore, management accounting practices significantly and positively influence the performance of family-owned SMEs. Moreover, networking orientation positively significantly moderates the relationship between succession planning, management accounting and performance of family-owned SMEs. The empirical findings of the current study facilitate the family-owned SMEs and policymakers in understanding the significance of succession planning and management accounting towards the performance and also enable them to understand the role of networking orientation
\end{abstract}

Keywords

SMEs, Small Medium Enterprises, Performance, Financial Performance, Non-Financial Performance, Succession Planning, Management Accounting, Networking Orientation, Family-owned SMEs

Article Received: 10 August 2020, Revised: 25 October 2020, Accepted: 18 November 2020

\section{Introduction}

Since the emergence of globalization, the domestic as well as international markets are getting competitive. The use of innovative technology and environmental sustainability remains the point of discussion among the academicians, researchers, industry, and policymakers. Approximately, 95 of registered businesses across the world were owned and operated by the families. These businesses contribute significantly in terms of employment generation, exports, and economic growth. Across the world, approximately 30 to 70 percent of listed companies were categorized as family-owned businesses. Similarly, approximately 95 percent of SMEs were owned by the families and generate significantly in employment generation, exports, and economic growth. For example; the USA and Canada have percent businesses are registered as family-owned (Ibrahim, Soufani, Poutziouris, \& Lam, 2004) on the other hand, family businesses are reported in Australia around half of all businesses (Cano-Rubio, Fuentes-Lombardo, \& VallejoMa, 2017). Pakistan owned around 70 percent listed companies as family businesses. Likewise, the literature documented that in America 99 percent of businesses are registered under SMEs (Fanta, 2015), consequently, around 99.8 percent of total businesses registered under SMEs in the European Union (Oricchio, Lugaresi, Crovetto, \& Fontana, 2017). In the case of Asian countries china, 99 percent (Ren, Eisingerich, \& Tsai, 2015; Muriithi, 2017). Similarly, 99 percent of companies engaged in SMEs in Japan (Fanta, 2015). While, Indonesia is significantly represented its GDP by 60 percent and the number of employees is 97 percent (Doraisami, 2013). The contribution of SMEs in Pakistan is 80 percent in terms of non-agricultural employment and 40 percent of GDP (Abasyn, 2017).

The literature on the family-owned businesses documented that the most common and critical factor that affects the performance or sustainable growth of the family-owned businesses is succession planning (Saan, Enu-Kwesi, \& Nyewie, 2018). The survival rate is just 30 percent in the 2nd generation, 12 to 15 percent in 3rd generation and 3 to 5 percent survival rate in 4th generation (Ali \& Ali, 2018). However, there is no consensus in the literature on any single method for the succession planning process. Various studies from the westerns and eastern region test the relationship between succession planning and firm performance, however, these studies unable to consider the culture and family structure while measuring the succession planning (LeCounte, Prieto, \& Phipps, 2017; Hosseini, Barzoki, \& Isfahani, 2018; Njeri, Ngui, \& Mathenge, 2019). Asian countries have different family structures and cultures as compare to western countries (Dinh \& Calabrò, 2019). The family culture and structure are a bit different in South Asian countries like Pakistan and India (Masud, Nurunnabi, $\&$ Bae, 2018). So, considering family culture and structure the current study proposed the most suitable method for the measurement of succession planning is based on the social capital theory that includes the three dimensions' structural ties, cognitive ties, and relational ties.

Approximately, 41 percent of SMEs were operating the urban and 51 percent were in rural areas of Pakistan (Abrar, Bashir, Safeer, \& Shabbir, 2019). Due to a lack of proper 
education and access to the latest tools and techniques family-owned SMEs were operating on traditional patterns. For instance, these SMEs still use traditional accounting practices that do not facilitate them in proper planning, understanding the market's needs and demands and results in low performance and threat to survival (Carrera, 2017).

According to recent studies, due to the highly competitive market, the SMEs of developed countries implemented the management accounting practices (Shields \& Shelleman, 2016). These SMEs moving faster across the boarders from domestic to international markets, and capturing the domestic markets of developing countries ( $\mathrm{Li}, \mathrm{Li}$, Goerzen, \& Shi, 2018). The family-owned SMEs were unable to compete in international as well as in domestic markets if they are unable to understand or predict the needs and demands of the future (Baporikar, 2019). Therefore, this current study proposed to test the impact of management accounting practices on the performance of family-owned SMEs businesses to compete in international and domestic markets. Furthermore, the literature explained management accounting practices including costing, budgeting, responsibility center reporting, and analysis of decisionmaking (Cuzdriorean, 2017).

Literature on family-owned SMEs also indicates that family businesses usually work in family intra-network (O'Brien, Minjock, \& Colarelli, 2018). In which all the family businesses from the same family share their experiences with the other family members and do not consider the nature, size, and structure of businesses (Fletcher, De Massis, \& Nordqvist, 2016). In current competitive environment businesses need to have the relevant information about their sector so family-owned SMEs need to have networking orientation. Literature affirms that networking orientation influences the relationship between succession planning, management accounting, and firm performance (Dieguez-Soto, Manzaneque, \& GonzalezGarcla, 2019). Hence, the current study considers the networking orientation as a moderating variable.

The current study will facilitate the family-owned SMEs, academicians, and policymakers in understanding the role of succession planning and its significance towards the survival and sustainable performance. Furthermore, the finds of the current study will facilitate the policymakers in understanding how management accounting practices influence the performance of SMEs which eventually influences the economic growth. The current study also going to provide guidelines to SMEs and policymakers on the significance of networking orientation towards the performance of family-owned SMEs.

\section{Literature Review}

Enough literature has been documented in the domain of family-owned SMEs in developed and developing economies. Literature on family-owned SMEs concludes that succession planning is the most critical factor that influences the survival and sustainable performance. Various techniques were used in literature for the measurement of succession planning in the developed and developing economies (Bills, Lisic, \& Seidel, 2017; Aboradi \& Masari, 2018; Wayland, 2019). However, literature does not consider the role of family structure and culture which is the most important factor in the succession planning process (Michel \& Kammerlander, 2015; Ghee, Ibrahim, \& AbdulHalim, 2015). Moreover, literature shows that family structure and culture significantly influence the performance of family-owned businesses (Brettel, Chomik, \& Flatten, 2015; Werner, Schröder, \& Chlosta, 2018). Literature affirms that succession planning has a positive and significant impact on performance however, no unique and appropriate method for the measurement of succession planning (Zhang \& Qu, 2016). The current study considered the social capital theory for the measurement of succession planning while considering the family structure and culture. The dimensions of social capital theory include; structural ties, cognitive ties and relational ties (Bizri, 2016). These dimensions considered in the current study to measure the succession planning. Based on the above discussion the current study proposed that hypothesis:

\section{H1: Succession planning significantly influences the performance of family-owned businesses.}

Family characteristics and bindings based on the family network categorized as structural ties. It also includes the interaction among the family members on the business and level of understanding among the family members (Filser, De Massis, Gast, \& Kraus, 2018). The higher the frequency of interaction among the family members will positively and significantly influence the performance of family-owned SMEs (Agyapong, Ellis, \& Domeher, 2016).

Structural ties define the family characteristics and binding of family members for the betterment of family and business. These ties also known as familiar ties (Mowen \& Visher, 2016). Several studies in literature documented that family influence significantly influence the succession planning process or selection of a successor (Gomba \& Kele, 2016; Saan, Enu-Kwesi, \& Nyewie, 2018). However, even though for effective succession planning process strong structural ties are important. The frequency of interaction among the family members positively and significantly influence the firm performance and succession planning process (Pearson, Carr, \& Shaw, 2008). Using social capital theory, the current study considered the structural ties as a dimension to measure the succession planning. Because family ties significantly influence the succession planning process (Bizri, 2016).

\section{H1a: Structural has a positive and significant impact on the performance of family-owned businesses.}

Cognitive ties defined the share vision and mission of family members, this is based on the family closeness, culture, stories, and common language. The cognitive ties establish when all the family members share the same vision, ideas, and thoughts regarding the business (Bizri, 2016). Being a family member, every individual follows the same vision as a steward of business, so this positively influences the organizational performance and significantly linked with the succession planning process (Discua Cruz, Howorth, \& Hamilton, 2013). Hence, the current study proposed; 
H1b: Cognitive has a positive and significant impact on the performance of family-owned businesses.

Relational ties defined as the frequency of interaction or meetings of family members regarding the family business, this process facilitates in establish a level of trust among the family members and their sharing the vision leads to an effective succession planning process and firm performance (Bizri, 2016). The relational ties based on the trust and obligation among the family members. The trust leads towards the collectivism instead of individual identity, and obligation leads to unique goals (Arregle, Hitt, Sirmon, \& Very, 2007). The relational ties significantly influence the succession planning process along with firm performance. Hence, the current study proposed;

H1c: Relational has a positive and significant impact on the performance of family-owned businesses.

Management accounting practices were being used by the corporate sector and facilitate in attaining a competitive advantage in a highly competitive environment. As compared that SMEs operating in domestic and international still use traditional accounting systems which is not enough to compete in domestic as well as international markets (Dominguez \& Mayrhofer, 2017). Several studies documented the positive and significant impact of management accounting on the performance of familyowned businesses in the corporate sector and used various methods for the measurement of management accounting (Bisogno \& Vaia, 2017; Quinn, Hiebl, Moores, \& Craig, 2018). Recent literature indicates that SMEs need to use to the management accounting practices instead of traditional accounting practices otherwise unable to compete in highly competitive markets because of traditional accounting system-based accounting records only (Andersen \& Samuelsson, 2016; Azudin \& Mansor, 2018). Based on literature the current study proposed to test the impact of management accounting practices on performance of family-owned SMEs. There are four dimensions of management accounting include; costing system, budgeting system, responsibility reporting center and analysis of decision making. Based on the above discussion the current study proposed that hypothesis:

H2: Management accounting has a significant impact on the performance of family-owned businesses.

Networking facilitates the businesses in the acquisition, generation, and dissemination information across the sector and related sector which facilitates understanding the current market situation as well as future needs and demands (Edler \& Yeow, 2016). Networking orientation is a strategic tool being used by the corporate as well as SMEs to boost the business performance in domestic and international markets (Mu, Thomas, Peng, \& Di Benedetto, 2017). Moreover, literature indicates that family-owned SMEs prefer to word in family intra-network and do not consider the structure and nature of business. Family-owned SMEs do not consider the networking orientation as a strategic tool to attain a higher level of performance (Karami \& Tang, 2019). The literature indicates a positive and significant relationship between networking orientation and firm performance. Furthermore, the literature showed that networking orientation moderate the relationship between organizational capabilities and performance (Dans, Adomak, Damoah, \& Uddin, 2016) the direction of the relationship as moderating construct is positive and significant (Asad, Sharif, \& Hafeez, 2016). Based on the literature review the current study considered the networking orientation as a moderating factor on the relationship between succession planning, management accounting and performance in the domain of family-owned businesses. The current study proposed that hypothesis:

\section{H3: Networking orientation has a significant impact on the performance of the family-owned business.}

H4: Networking orientation moderates the relationship between succession planning and performance of familyowned businesses.

H5: Networking orientation moderates the relationship between management accounting practices and the performance of the family-owned business.

Competitive advantage and a higher level of performance was previously discussed under the resource-based view theory (Bromiley \& Rau, 2016). Resource-based view theory explains that organizational competencies and skills to improve the higher-level performance. Literature affirms that successor remains the key resource that significantly influences the performance of family businesses (İpek, 2018). Moreover, management accounting practices were categorized as unique competency which facilitate SMEs in attaining competitive advantage in domestic and as well as in international markets (Rehman \& Anwar, 2019). The current study operationalizes succession planning, management accounting practices, and networking orientation as critical organizational resources that facilitate in attaining the competitive advantage or high performance of family-owned SMEs. The current intends to contribute in theory by testing succession planning, management accounting practices, and networking orientation on the performance of family-owned SMEs. This study will enhance the body of literature empirically testing the relationship between succession planning, management accounting, and performance of family-owned with the moderating role of networking orientation. 


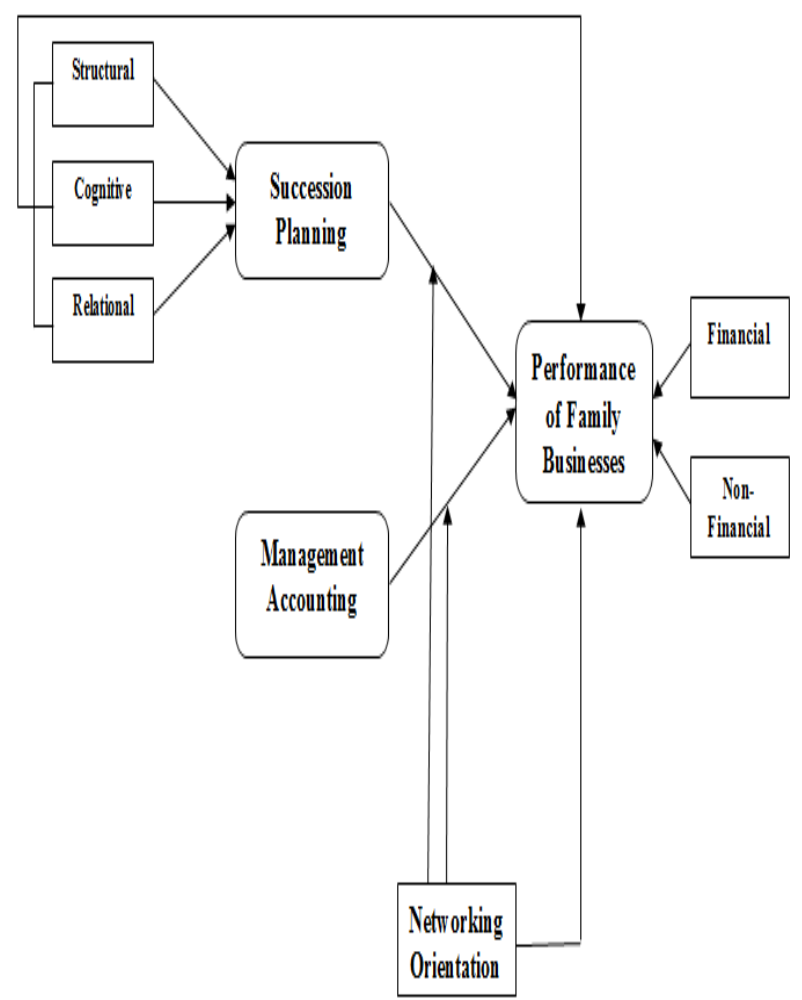

Figure 1: Theoretical Framework

\section{Methodology}

The underpinning objective of the current study is to test the moderating effect of networking orientation on the succession planning and management accounting on the performance of family-owned SMEs. The current study is basic research and quantitative while considering the research objective current study based on the positivism paradigm. The positivism paradigms allow to generalize the results of current based on the sports industry of Punjab, Pakistan using the simple random sampling technique and research methodology. The current study employed the adapted self-administrated questionnaire to collect the data from the sports sector in Punjab.

The current study is using the survey-based method for data collection. To improve the response rate and quality of responses questionnaires will be self-administrated. The questionnaire is 5-Likert's scale because it is most common in survey-based methods and easy to understand for respondents (Cooper \& Schindler, 2006).

\section{Research Procedure and Contributor}

Approximately 12,000 SMEs were registered under the sports goods industry of Pakistan, out of which approximately 8,000 manufacturing SMEs were registered in Punjab which is 67 percent. 6,800 SMEs were registered under the Sialkot Chamber of Commerce that is 85 percent of SMEs operating in Punjab and 56 percent of total SMEs registered in Pakistan under the sports goods industry (Government of Punjab, 2018). The sports goods industry of Punjab, Pakistan is considered as the target population for the current study based on the industry contribution to GDP and total exports of Pakistan. Based on the information provided the representative of the Sialkot chamber of commerce 99 percent of firms operating the sports goods industry is owned and operated by the families. The minimum sample size of 136 was calculated using a $\mathrm{G}^{*}$ power calculator with the effect size 0.30 at a 95 percent level of significance. Furthermore, according to Krejcie and Morgan (1970) the required sample size based on the known population is 306 . The respondents of the current study will be managers/owners of SMEs because they are true representatives of the firm. Furthermore, the demographic information also facilitates in the categorization of familyowned and non-family businesses. The current study only considered the family-owned SMEs from the manufacturing sector.

Data Analysis will follow the following steps; first; screening and data cleaning, normality test, descriptive statistics, to test the reliability and validity test Cronbach's alpha to ensure the internal consistency of measured constructs. Pearson correlation used to test the relationship between the measured constructs (Arpaci, 2016). Moreover, multiple regression techniques will be performed to investigate the predictive capacity of independent variables towards the dependent variable. In addition to that, the moderating effect of networking orientation. Multiple hierarchal regression techniques adopted to test the effect of moderating variables on the relationship between independent variables and dependent variables using PLSSEM. The current study using PLS-SEM because the current study is not theory testing (Hair Jr, Matthews, \& Matthews, 2017).

\section{Measures}

The current study used the survey-based method and scales for the measurement of relevant constructs were adapted from the well-established literature based on the 5-Likert scale. 1 (Strongly to 5 (Strongly Agree).

\section{Dependent Variables}

The subjective performance of Family-owned SMEs includes two perspectives: financial performance and nonfinancial performance perspectives. Serval studies considered the financial performance and various studies also considered the non-financial performance (RodriguezFernandez, 2016; Platonova, Asutay, Dixon, \& Mohammad, 2018; Lansiluoto, Joensuu-Salo, \& Varamaki, 2019). However, for the better understanding current study considered both factors as family-owned SMEs do not solely look at the financial performance. The underpinning objective of family-owned is long-term survival instead of short-term profits (Ha, Lo, \& Wang, 2016). This current study measures performance with two perspectives: financial and non-financial performance which is adapted by (Ho, Ahmad, \& Ramayah, 2016).

\section{Independent Variables}

Succession planning is a multi-dimensional include; structural, cognitive (family stewardship) and relational (Trust and obligation). The current study adapted the scale from (Bizri, 2016). 
Management accounting is a multidimensional construct that includes; costing system, budgeting system, responsibility center reporting and analysis of decision making that are adapted from the previous research study (Armitage, Webb, \& Glynn, 2016).

The networking orientation is taken as a moderating construct and unidimensional. The measures of networking orientation are adapted from (Spriggs, Yu, Deeds, \& Sorenson, 2013).

\section{Results and analysis}

The measurement model is assessed using factor analysis, discriminant validity, and construct reliability and validity (Henseler, Ringle, \& Sinkovics, 2009). The assessment of reliability and validity is mandatory before moving to structural model assessment (Hair, Black, Babin, \& Anderson, 2006). The correction matrix is being used to assess the nature and direction of the relationship among the variables. The most appropriate method of factor analysis is CFA (Law, Stewart, Letts, Pollock, \& Bosc, 1998).

The findings of the two tail Pearson correction were reported in table 1 . The initial assessment of the correction matrix facilitates in understanding the nature and direction of the relationship among the constructs under consideration. The correlation matrix of the current study indicates all the constructs have a positive relationship. Furthermore, correlation values among the constructs and their dimension is not that high so there are no or fewer chances of multicollinearity.

Table 1: Correlation Matrix

\begin{tabular}{|l|c|c|c|c|c|c|c|c|c|c|}
\hline & STR & COG & REL & CS & BS & RC & AD & NO & FP & NFP \\
\hline Structural & 1.00 & & & & & & & & & \\
\hline Cognitive & 0.56 & 1.00 & & & & & & & & \\
\hline Relational & 0.46 & 0.75 & 1.00 & & & & & & & \\
\hline Costing system & 0.38 & 0.40 & 0.16 & 1.00 & & & & & & \\
\hline Budgeting system & 0.61 & 0.47 & 0.35 & 0.59 & 1.00 & & & & & \\
\hline $\begin{array}{l}\text { Responsibility center } \\
\text { reporting }\end{array}$ & 0.68 & 0.55 & 0.65 & 0.41 & 0.52 & 1.00 & & & & \\
\hline $\begin{array}{l}\text { Analysis for decision } \\
\text { making }\end{array}$ & 0.60 & 0.68 & 0.68 & 0.48 & 0.48 & 0.69 & 1.00 & & & \\
\hline Networking Orientation & 0.55 & 0.48 & 0.72 & 0.59 & 0.67 & 0.45 & 0.41 & 1.00 & & \\
\hline Financial Performance & 0.34 & 0.47 & 0.40 & 0.52 & 0.39 & 0.46 & 0.36 & 0.48 & 1.00 & \\
\hline Non-Financial & 0.43 & 0.56 & 0.53 & 0.43 & 0.44 & 0.35 & 0.44 & 0.37 & 0.47 & 1.00 \\
\hline
\end{tabular}

* $\mathrm{STR}=$ structural, $\mathrm{COG}=$ cognitive, $\mathrm{REL}=$ relational, $\mathrm{CS}=$ Costing system, $\mathrm{BS}=$ Budgeting system, $\mathrm{RC}=$ Responsibility center reporting, $\mathrm{AD}=$ Analysis for decision making, $\mathrm{FP}=$ financial performance, and $\mathrm{NFP}=$ non-financial performance.

\section{Evaluation of Measurement Model}

\section{Factor analysis}

Factor analysis is also known as a data reduction technique because it facilitates in combining a large dataset into few variables. This technique is based on the common variance. The scale of all constructs was adapted hence there is will be no issue with reliability and validity. Moreover, the results of loading concerning their constructs indicate a loading value greater than 0.50 expect one from the costing system and responsibility center reporting indicate a loading of less than 0.50 were dropped from the analysis. The cut-off value for the factor loading is 0.50 as suggested in the literature (Tzeng, Chiang, \& Li, 2007). The results of factor analysis were reported in table 2 .

Table 2: Factor Loading

\begin{tabular}{|l|l|l|l|l|l|l|l|l|l|l|}
\hline & STR & COG & REL & CS & BS & RC & AD & NO & FP & NFP \\
\hline Sps1 & 0.78 & & & & & & & & & \\
\hline Sps2 & 0.70 & & & & & & & & \\
\hline Sps3 & 0.60 & & & & & & & & & \\
\hline Sps4 & 0.79 & & & & & & & & & \\
\hline Sps5 & 0.84 & & & & & & & & & \\
\hline Sps6 & 0.78 & & & & & & & & & \\
\hline Sps7 & 0.67 & & & & & & & & & \\
\hline
\end{tabular}




\begin{tabular}{|c|c|c|c|c|c|c|c|c|c|c|}
\hline Sps8 & 0.62 & & & & & & & & & \\
\hline Sps9 & 0.52 & & & & & & & & & \\
\hline Spc1 & & 0.649 & & & & & & & & \\
\hline Spc2 & & 0.628 & & & & & & & & \\
\hline $\mathrm{Spc} 3$ & & 0.754 & & & & & & & & \\
\hline Spc4 & & 0.812 & & & & & & & & \\
\hline Spc5 & & 0.698 & & & & & & & & \\
\hline Spc6 & & 0.590 & & & & & & & & \\
\hline Spc7 & & 0.849 & & & & & & & & \\
\hline Spc8 & & 0.835 & & & & & & & & \\
\hline Spc9 & & 0.734 & & & & & & & & \\
\hline Spc10 & & 0.760 & & & & & & & & \\
\hline Spr1 & & & 0.881 & & & & & & & \\
\hline Spr2 & & & 0.768 & & & & & & & \\
\hline Spr3 & & & 0.748 & & & & & & & \\
\hline Spr4 & & & 0.659 & & & & & & & \\
\hline Spr5 & & & 0.640 & & & & & & & \\
\hline Mac1 & & & & 0.52 & & & & & & \\
\hline Mac2 & & & & 0.523 & & & & & & \\
\hline Mac3 & & & & 0.639 & & & & & & \\
\hline Mac4 & & & & 0.732 & & & & & & \\
\hline Mac5 & & & & 0.415 & & & & & & \\
\hline Mac6 & & & & 0.591 & & & & & & \\
\hline Mab1 & & & & & 0.748 & & & & & \\
\hline Mab2 & & & & & 0.710 & & & & & \\
\hline Mab3 & & & & & 0.782 & & & & & \\
\hline Mar1 & & & & & & 0.88 & & & & \\
\hline Mar2 & & & & & & 0.74 & & & & \\
\hline Mar3 & & & & & & 0.67 & & & & \\
\hline Mar4 & & & & & & 0.70 & & & & \\
\hline Mar5 & & & & & & 0.48 & & & & \\
\hline Maa1 & & & & & & & 0.79 & & & \\
\hline Maa2 & & & & & & & 0.86 & & & \\
\hline Maa3 & & & & & & & 0.72 & & & \\
\hline Maa4 & & & & & & & 0.82 & & & \\
\hline Maa5 & & & & & & & 0.90 & & & \\
\hline No1 & & & & & & & & 0.54 & & \\
\hline No2 & & & & & & & & 0.78 & & \\
\hline No3 & & & & & & & & 0.86 & & \\
\hline No4 & & & & & & & & 0.85 & & \\
\hline No5 & & & & & & & & 0.66 & & \\
\hline No6 & & & & & & & & 0.76 & & \\
\hline Pf1 & & & & & & & & & 0.53 & \\
\hline Pf2 & & & & & & & & & 0.68 & \\
\hline Pf3 & & & & & & & & & 0.55 & \\
\hline Pf4 & & & & & & & & & 0.69 & \\
\hline Pf5 & & & & & & & & & 0.68 & \\
\hline Pnf1 & & & & & & & & & & 0.64 \\
\hline Pnf2 & & & & & & & & & & 0.73 \\
\hline Pnf3 & & & & & & & & & & 0.66 \\
\hline Pnf4 & & & & & & & & & & 0.80 \\
\hline Pnf5 & & & & & & & & & & 0.74 \\
\hline Pnf6 & & & & & & & & & & 0.68 \\
\hline
\end{tabular}

Four statistical techniques being followed and suggested in the literature for the assessment of convergent validity includes; Cronbach' Alpha, rho_A, composite reliability, and average variance extract. The findings of convergent validity were reported in table 3 . The cut-off value of Cronbach Alpha is 0.70 in the current study (Taber, 2018). The results of convergent validity indicate that for all the measured constructs the value of Cronbach alpha is greater than 0.70 . The second technique is roh_A which is considered as the most important method for the assessment of internal consistency as compare to Cronbach alpha. The cut off value of roh_A is 0.70 (Taber, 2018) and the construct indicates higher value concerning cut off value. The composite reliability or construct reliability is also being used for the assessment of internal consistency and the cut off value for composite reliability in the current study is also 0.70 . The findings indicate the values of the construct in case of composite reliability is greater than the threshold value. The last factor which is being used to assess the convergent validity is average variance extract (AVE) the 
threshold value is 0.50 (Ab Hamid, Sami, \& Sidek, 2017) constructs is much higher than the threshold value. and the findings show the value of AVE for the measured

Table 3: Convergent validity

\begin{tabular}{|l|c|c|c|c|}
\hline & $\begin{array}{c}\text { Cronbach's } \\
\text { Alpha }\end{array}$ & rho_A & $\begin{array}{c}\text { Composite } \\
\text { Reliability }\end{array}$ & AVE \\
\hline Structural & 0.86 & 0.88 & 0.89 & 0.79 \\
\hline Cognitive & 0.89 & 0.89 & 0.91 & 0.53 \\
\hline Relational & 0.79 & 0.81 & 0.85 & 0.65 \\
\hline Succession planning & 0.89 & 0.93 & 0.90 & 0.73 \\
\hline Costing system & 0.86 & 0.85 & 0.77 & 0.67 \\
\hline Budgeting system & 0.73 & 0.85 & 0.74 & 0.76 \\
\hline Responsibility center reporting & 0.73 & 0.80 & 0.82 & 0.66 \\
\hline Analysis for decision making & 0.91 & 0.75 & 0.74 & 0.72 \\
\hline Management Accounting & 0.72 & 0.86 & 0.76 & 0.62 \\
\hline Financial & 0.82 & 0.78 & 0.76 & 0.79 \\
\hline Non-Financial & 0.79 & 0.73 & 0.80 & 0.52 \\
\hline Performance & 0.75 & 0.81 & 0.81 & 0.63 \\
\hline
\end{tabular}

Discriminant validity is demonstrated to measure all the independent constructs that should not be highly related to each other. Table 4 reported the results of discriminant validity. For estimation of discriminant validity two approaches have been used in literature are Fornell-Larcker and Heterotrait-Monotrait (HTMT) (Al-Maroof \& AlEmran, 2018). According to previous literature the FornellLarcker has been condemned for the estimation of discriminant validity. This current study considers the HTMT approach for the estimation of discriminant validity.
Furthermore, two schools of thought have been introduced regarding the threshold value of HTMT to estimate discriminant validity. The first viewpoint has been introduced by (Gold, Malhotra, \& Segars, 2001) that explained the threshold value must not be higher than 0.90 on the other hand, the second viewpoint has to be introduced by (Kline, 2011) that explained threshold value must not be higher than 0.85 . For the estimation of discriminant validity this current study considers the cut off value of HTMT is 0.90 .

Table 4: Discriminant Validity

\begin{tabular}{|l|l|l|l|l|l|l|l|l|l|l|l|l|l|}
\hline & str & cog & Rel & sp & Cs & bs & Rc & ad & Ma & no & Fin & Nf & per \\
\hline Str & & & & & & & & & & & & \\
\hline Cog & 0.75 & & & & & & & & & & & \\
\hline Re & 0.15 & 0.35 & & & & & & & & & & & \\
\hline Sp & 0.63 & 0.23 & 0.36 & & & & & & & & & & \\
\hline Cs & 0.38 & 0.20 & 0.16 & 0.23 & & & & & & & & \\
\hline Bs & 0.61 & 0.47 & 0.35 & 0.51 & -0.09 & & & & & & & & \\
\hline Rc & 0.68 & 0.85 & 0.65 & 0.47 & 0.11 & 0.70 & & & & & & & \\
\hline Ad & 0.60 & 0.68 & 0.68 & 0.41 & 0.18 & 0.28 & 0.69 & & & & & & \\
\hline Ma & 0.72 & 0.49 & 0.62 & 0.31 & 0.23 & 0.56 & 0.34 & 0.29 & & & & & \\
\hline No & 0.55 & 0.38 & 0.52 & 0.49 & 0.19 & 0.37 & 0.55 & 0.51 & 0.88 & & & & \\
\hline Fin & 0.39 & 0.40 & 0.45 & 0.37 & 0.20 & 0.29 & 0.46 & 0.56 & 0.34 & 0.28 & & \\
\hline Nf & 0.32 & 0.27 & 0.33 & 0.43 & 0.03 & 0.64 & 0.45 & 0.44 & 0.35 & 0.33 & 0.47 & \\
\hline Per & 0.21 & 0.43 & 0.24 & 0.27 & 0.25 & 0.54 & 0.24 & 0.48 & 0.23 & 0.48 & 0.45 & 0.46 \\
\hline
\end{tabular}




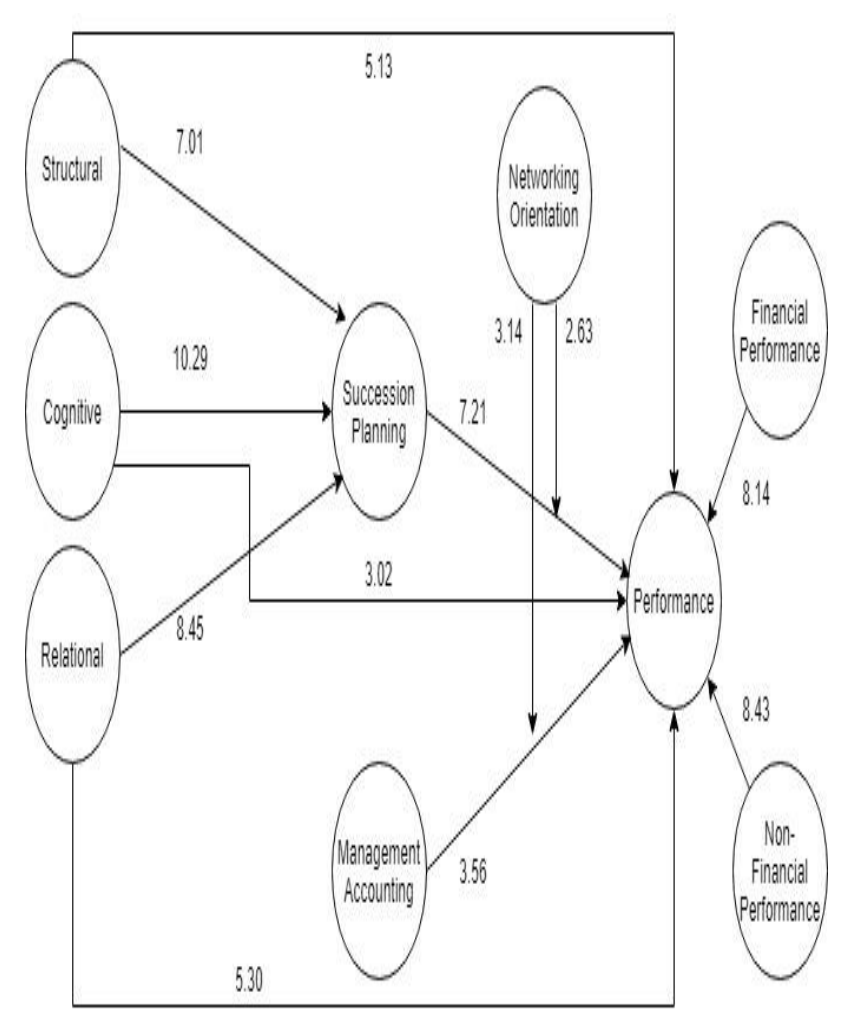

Figure 2: Structural Model

\section{Structural Model Assessment}

The structural model is used to presents the association between latent variable to latent variable while the estimation of structural model assessment is demonstrated to measure the constructs that are related to the underpinning theory (Proyer, 2017). PLS-SEM has been used to estimate the structural model assessment for the current study. For evaluation of the significance of the association between measured constructs table 5 reported the values of path coefficient, standard deviation, $t$ statistics value, and $\mathrm{p}$ value. Table 5 shows the results regarding structural, cognitive, and relational ties are positively and significantly related to succession planning. Moreover, the results show that succession planning, structural, cognitive and relational has a positive and significantly relation with performance $(\beta$ $=0.22, \mathrm{t}=7.21, \mathrm{p}<0.01 ; \beta=0.53, \mathrm{t}=5.13, \mathrm{p}<0.01 ; \beta=0.51$, $\mathrm{t}=3.02, \mathrm{p}<0.01 ; \beta=0.52, \mathrm{t}=5.30, \mathrm{p}<0.01)$ consequently this paper accepts $\mathrm{H} 1$ and H1a to H1c. The costing system, budgeting system, responsibility center reporting, analysis for decision making has a positive and significant relation with management accounting. Moreover, management accounting demonstrates a positive and significant relationship with the performance $(\beta=0.32, \mathrm{t}=3.56, \mathrm{p}<0.01)$ consequently we accept $\mathrm{H} 2$. Also, the anticipating value of networking orientation reported that $\mathrm{H} 3$ was accepted and demonstrates the positive but significant moderate relation with succession planning and performance $(\beta=0.22$., $\mathrm{t}=3.14$, $\mathrm{p}<0.01)$. Similarly, the anticipating value of networking orientation reported that $\mathrm{H} 4$ was accepted and demonstrates the positive but significant moderate relation with management accounting and performance $(\beta=0.21$., $\mathrm{t}=2.63$, $\mathrm{p}<0.01$ ) explained in table 5. All hypothesis testing is explained in table 5 .
Table 5: Testing of Hypothesis

\begin{tabular}{|c|c|c|c|c|c|}
\hline & & $\begin{array}{l}\text { Me } \\
\text { an }\end{array}$ & $\begin{array}{l}\text { S. } \\
\text { D }\end{array}$ & $\begin{array}{l}\text { T } \\
\text { Statis } \\
\text { tics } \\
\end{array}$ & $\begin{array}{l}\mathbf{P} \\
\text { Val } \\
\text { ues }\end{array}$ \\
\hline & $\begin{array}{l}\text { Structural->Succession } \\
\text { planning }\end{array}$ & $\begin{array}{l}0.5 \\
1\end{array}$ & $\begin{array}{l}0 . \\
07\end{array}$ & 7.01 & 0.00 \\
\hline & $\begin{array}{l}\text { Cognitive->Succession } \\
\text { planning }\end{array}$ & $\begin{array}{l}0.5 \\
4\end{array}$ & $\begin{array}{l}0 . \\
05\end{array}$ & 10.29 & 0.00 \\
\hline & $\begin{array}{l}\text { Relational->Succession } \\
\text { planning }\end{array}$ & $\begin{array}{l}0.3 \\
5\end{array}$ & $\begin{array}{l}0 . \\
04\end{array}$ & 8.45 & 0.00 \\
\hline $\begin{array}{l}\mathrm{H} \\
1\end{array}$ & $\begin{array}{l}\text { Succession planning- } \\
>\text { Performance }\end{array}$ & $\begin{array}{l}0.2 \\
2\end{array}$ & $\begin{array}{l}0 . \\
03\end{array}$ & 7.21 & 0.00 \\
\hline $\begin{array}{l}\mathrm{H} \\
1 \mathrm{a}\end{array}$ & Structural-> performance & $\begin{array}{l}0.5 \\
3\end{array}$ & $\begin{array}{l}0 . \\
10\end{array}$ & 5.13 & 0.00 \\
\hline $\begin{array}{l}\mathrm{H} \\
1 \mathrm{~b}\end{array}$ & Cognitive-> performance & $\begin{array}{l}0.5 \\
1\end{array}$ & $\begin{array}{l}0 . \\
16\end{array}$ & 3.02 & 0.00 \\
\hline $\begin{array}{l}\mathrm{H} \\
1 \mathrm{c}\end{array}$ & $\begin{array}{l}\text { Relational-> } \\
\text { performance }\end{array}$ & $\begin{array}{l}0.5 \\
2\end{array}$ & $\begin{array}{l}0 . \\
10\end{array}$ & 5.30 & 0.00 \\
\hline & $\begin{array}{l}\text { Costing } \\
\text { >Management } \\
\text { accounting }\end{array}$ & $\begin{array}{l}0.4 \\
4\end{array}$ & $\begin{array}{l}0 . \\
09\end{array}$ & 4.89 & 0.00 \\
\hline & $\begin{array}{l}\text { Budgeting } \\
>\text { Management } \\
\text { accounting }\end{array}$ & $\begin{array}{l}0.2 \\
9\end{array}$ & $\begin{array}{l}0 . \\
08\end{array}$ & 3.63 & 0.00 \\
\hline & $\begin{array}{l}\text { Responsibility center } \\
\text { reporting-> Management } \\
\text { accounting }\end{array}$ & $\begin{array}{l}0.5 \\
9\end{array}$ & $\begin{array}{l}0 . \\
19\end{array}$ & 3.11 & 0.00 \\
\hline & $\begin{array}{l}\text { Analysis for decision } \\
\text { making-> Management } \\
\text { accounting }\end{array}$ & $\begin{array}{l}0.6 \\
1\end{array}$ & $\begin{array}{l}0 . \\
08\end{array}$ & 7.63 & 0.00 \\
\hline $\begin{array}{l}\mathrm{H} \\
2\end{array}$ & $\begin{array}{l}\text { Management } \\
\text { accounting- } \\
\text { > Performance } \\
\end{array}$ & $\begin{array}{l}0.3 \\
2\end{array}$ & $\begin{array}{l}0 . \\
09\end{array}$ & 3.56 & 0.00 \\
\hline & $\begin{array}{l}\text { Financial Performance- } \\
\text { >Performance }\end{array}$ & $\begin{array}{l}0.5 \\
7\end{array}$ & $\begin{array}{l}0 . \\
07\end{array}$ & 8.14 & 0.00 \\
\hline & $\begin{array}{l}\text { Non-Financial } \\
\text { Performance- } \\
\text { >Performance } \\
\end{array}$ & $\begin{array}{l}0.5 \\
9\end{array}$ & $\begin{array}{l}0 . \\
07\end{array}$ & 8.43 & 0.00 \\
\hline $\begin{array}{l}\mathrm{H} \\
3\end{array}$ & $\begin{array}{l}\text { Moderating Effect } 1-> \\
\text { Performance }\end{array}$ & $\begin{array}{l}0.2 \\
2\end{array}$ & $\begin{array}{l}0 . \\
07\end{array}$ & 3.14 & 0.00 \\
\hline $\begin{array}{l}\mathrm{H} \\
4\end{array}$ & $\begin{array}{l}\text { Moderating Effect } 2-> \\
\text { Performance }\end{array}$ & $\begin{array}{l}0.2 \\
1\end{array}$ & $\begin{array}{l}0 . \\
08\end{array}$ & 2.63 & 0.01 \\
\hline
\end{tabular}

\section{Discussion and Conclusions}

The underpinning objective of the current study is to test the impact of succession planning (structural, cognitive, and relational ties) and management accounting (costing system, budgeting system, responsibility center reporting, and analysis for decision making) on the performance (financial and non-financial) of family-owned SMEs. The current study considered the resource-based view as underpinning theory. Resource-based view theory claims that organizational capabilities and skills leads to competitive advantage or a higher level of performance (Mao, Liu, Zhang, \& Deng, 2016). The literature on family-owned SMEs affirms that the succession planning process or selection of successor is a critical resource that ensures the survival and sustainability of family-owned SMEs (Saan, Enu-Kwesi, \& Nyewie, 2018). However, there is no unique 
or a single acceptable process for succession planning. The current study considered the succession planning based on the social capital theory while considering the family structure and culture. None of the studies in literature so far documented the succession planning impact on the performance under the resource-based view theory. The management accounting practices are defined as set of skills and competencies that organizations hold to achieve sustainable performance (Hopper \& Bui, 2016). Most of the studies test the impact of management accounting practices on the firm performance at the corporate level (Joshi \& Li, 2016; Amoako, Marfo, Gyabaah, \& Owi, 2017; Rikhardsson \& Yigitbasioglu, 2018) however, only limited literature on SMEs discuss the significance of management accounting practices towards the performance of SMEs but there is no empirical evidence (Azudin \& Mansor, 2018; Uyar, 2019). The current study considered the management accounting practices as competency or skill under the resource-based view theory to test its impact on the performance. Serval studies in literature documented that networking orientation significantly influences the performance of SMEs (Adomako, Danso, Boso, \& Narteh, 2018; Karami \& Tang, 2019). However, literature unable to concludes its impact on the performance of family-owned SMEs (Mashavira, Chipunza, \& Dzansi, 2019). The current study considered the networking orientation as a moderating factor in the relationship between succession planning, management accounting and performance (Spriggs, Yu, Deeds, \& Sorenson, 2013).

The current study affirms that succession planning (structural, cognitive, and relational ties) positively and significantly influence the performance of family-owned SMEs. Furthermore, Structural, cognitive, and relational ties individually had a positive and significant relationship with the firm performance of Family-Owned SMEs. Similar findings previously reported in the literature however, the current study defined succession planning based on social capital theory (LeCounte, Prieto, \& Phipps, 2017). The results affirm that management accounting practices have a positive and significant influence on firm performance of family-owned SMEs. The findings of the current study are well aligned with the literature (Giovannoni, Maraghini, \& Riccaboni, 2011). Furthermore, the networking orientation shows a positive and significant relationship with performance. Network orientation indicates a moderating effect on the relationship between succession planning, management accounting, and performance of family-owned SMEs.

The family-owned SMEs in the sports goods industry of Pakistan were operating on the traditional patterns and old techniques being followed. The findings of the current study affirm the effective succession planning, management accounting practices, and networking orientation significantly important for the performance of family-owned SMEs. Furthermore, networking orientation moderates the relationship which affirms that in the presence of networking orientation the explains of succession planning and management accounting practice will better explain the performance of family-owned SMEs.

The current study facilitates SMEs particularly from the sports goods industry of Pakistan, academicians, and policymakers in understanding the role of succession planning and management accounting practices towards the performance of family-owned SMEs. The current study also contributes towards the body of literature by testing the succession planning and management accounting practices under the resource-based view theory. Furthermore, the future studies need to consider the impact of market orientation as a predictor of performance because previous literature affirms that family-owned SMEs not well equipped with new marketing tools and technique which also affect the competitive position in domestic as well as in international markets (Zainal, Parinsi, Hasan, Said, \& Ak, 2018; Dahms, 2019). Future studies need to test this model on other sectors like surgical, leather, and chemical etc. in Pakistan as well as in South Asian regional because South Asian economies have similar culture and family structure approximately (Maroof, Hussain, Jawad, \& Naz, 2019)

\section{References}

[1] Ab Hamid, R. M., Sami, W., \& Sidek, M. M. (2017). Discriminant validity assessment: Use of Fornell \& Larcker criterion versus HTMT criterion. In Journal of Physics: Conference Series, 890(1), 12-163.

[2] Abasyn, J. (2017). An Exploratory Evidence of the Types of Challenges and Opportunities Perceived by the Small and Medium Enterprises (SMEs) in the Apparel Export Sector of Pakistan. University Journal of Social Sciences, 10(2), 373-395.

[3] Aboradi, S. M., \& Masari, R. (2018). SMALL MEDIUM SIZED ENTERPRISES IN SAUDI ARABIA: CONCEPTUALIZING AN EFFECTIVE SUCCESSION PLANNING. International Journal of Accounting, 3(11), 14-32.

[4] Abrar, M., Bashir, M., Safeer, A. A., \& Shabbir, R. (2019). Pakistani Ready-made Garments Industry Export Competitiveness: Evaluation in The Context of Porter's Diamond Theory. Revista Publicando, 5(18), 228-246.

[5] Adomako, S., Danso, A., Boso, N., \& Narteh, B. (2018). Entrepreneurial alertness and new venture performance: Facilitating roles of networking capability. International Small Business Journal, 36(5), 453-472.

[6] Agyapong, A., Ellis, F., \& Domeher, D. (2016). Competitive strategy and 
performance of family businesses: moderating effect of managerial and innovative capabilities. Journal of Small Business \& Entrepreneurship, 28(6), 449477.

[7] Ali, Z. M., \& Ali, M. S. (2018). Why Are Family Owned Businesses Unable to Sustain Beyond the Second Generation. Global Management Journal for Academic \& Corporate Studies, 8(2), 128-143.

[8] Al-Jaroodi, J., \& Mohamed, N. (2012). Service-oriented middleware: A survey. Journal of Network and Computer Applications, 35(1), 211-220.

[9] Al-Maroof, A. R., \& Al-Emran, M. (2018). Students acceptance of Google classroom: An exploratory study using PLS-SEM approach. International Journal of Emerging Technologies in Learning, 13(6), 112-123.

[10] Amoako, O. K., Marfo, O. E., Gyabaah, N. E., \& Owi. (2017). Achieving a Sustainable Business: The Role of Environmental Management Accounting in Corporate Governance. International Journal of Academic Research in Accounting, Finance and Management Sciences, 7(4), 11-20.

[11] Andersen, J., \& Samuelsson, J. (2016). Resource organization and firm performance: How entrepreneurial orientation and management accounting influence the profitability of growing and non-growing SMEs. International Journal of Entrepreneurial Behaviour \& Research, 22(4), 466-484.

[12] Andrew, P. D., Pedersen, M. P., \& McEvoy, D. C. (2019). Research methods and design in sport management. Human Kinetics Publishers.

[13] Armitage, M. H., Webb, A., \& Glynn, J. (2016). The use of management accounting techniques by small and medium-sized enterprises: a field study of Canadian and Australian practice. Accounting Perspectives, 15(1), 31-69.

[14] Arpaci, I. (2016). Understanding and predicting students' intention to use mobile cloud storage services. Computers in Human Behavior, 58(1), 150-157.

[15] Arregle, L. J., Hitt, A. M., Sirmon, G. D., $\&$ Very. (2007). The development of organizational social capital: Attributes of family firms. Journal of management studies, 44(1), 73-95.

[16] Asad, M., Sharif, N. M., \& Hafeez, M. (2016). Moderating effect of network ties on the relationship between entrepreneurial orientation, market orientation, and performance of MSEs. Paradigms: A Research Journal of Commerce, Economics, and Social Sciences, 10(2), 69-76.

[17] Azudin, A., \& Mansor, N. (2018). Management accounting practices of SMEs: The impact of organizational DNA, business potential and operational technology. Asia Pacific Management Review, 23(3), 222-226.

[18] Baporikar, N. (2019). Influence of Business Competitiveness on SMEs Performance. International Journal of Productivity Management and Assessment Technologies. International Journal of Productivity Management and Assessment Technologies, 7(2), 1-25.

[19] Bills, L. K., Lisic, L. L., \& Seidel, A. T. (2017). Do CEO succession and succession planning affect stakeholders' perceptions of financial reporting risk? Evidence from audit fees. The Accounting Review, 92(4), 27-52.

[20] Bisogno, M., \& Vaia, G. (2017). The role of management accounting in family business succession. African Journal of Business Management, 11(21), 619-629.

[21] Bizri, R. (2016). Succession in the family business: drivers and pathways. International Journal of Entrepreneurial Behavior \& Research, 22(1), 134-154.

[22] Brettel, M., Chomik, C., \& Flatten, C. T. (2015). How organizational culture influences innovativeness, proactiveness, and risk-taking: Fostering entrepreneurial orientation in SMEs. Journal of small business management, 53(4), 868-885. 
[23] Bromiley, P., \& Rau, D. (2016). Operations management and the resource based view: Another view. Journal of Operations Management, 41(1), 95-106.

[24] Cano-Rubio, M., Fuentes-Lombardo, G., \& Vallejo-Ma. (2017). Influence of the lack of a standard definition of "family business" on research into their international strategies. European Research on Management and Business Economics, 23(3), 132-146.

[25] Carrera, N. (2017). What Do We Know about Accounting in Family Firms? Journal of Evolutionary Studies in Business, 2(2), 97-159.

[26] Cooper, D. R., \& Schindler, P. S. (2006). Business Research Methods. Chicago: McGraw-Hill Irwin.

[27] Cuzdriorean, D. D. (2017). The use of management accounting practices by Romanian small and medium-sized enterprises: A field study. Journal of Accounting and Management Information Systems, 16(2), 291-312.

[28] Dahms, S. (2019). The influence of competences and institutions on the international market orientation in foreignowned subsidiaries. European Journal of International Management, 13(1), 354380.

[29] Dans, A., Adomak, S., Damoah, O. J., \& Uddin, M. (2016). Risk-taking propensity, managerial network ties and firm performance in an emerging economy. The Journal of Entrepreneurship, 25(2), 155183.

[30] Dieguez-Soto, J., Manzaneque, M., \& Gonzalez-Garcla. (2019). A study of the moderating influence of $R \& D$ intensity on the family management-firm performance relationship: Evidence from Spanish private manufacturing firms. Business Research Quarterly, 105-118.

[31] Dinh, Q. T., \& Calabrò, A. (2019). Asian family firms through corporate governance and institutions: a systematic review of the literature and agenda for future research.
International Journal of Management Reviews, 21(1), 50-75.

[32] Discua Cruz, A., Howorth, C., \& Hamilton, E. (2013). Intrafamily entrepreneurship: The formation and membership of family entrepreneurial teams. Entrepreneurship Theory and Practice, 37(1), 17- 46.

[33] Dominguez, N., \& Mayrhofer, U. (2017). Internationalization stages of traditional SMEs: Increasing, decreasing and reincreasing commitment to foreign markets. International Business Review, 26(6), 1051-1063.

[34] Doraisami ， A. (2013). Fiscal Policy Challenges in Developing Countries: The Indonesian Experience in Responding to the Global Financial Crisis. Journal of Southeast Asian Economies, 30(3), 322333.

[35] Edler, J., \& Yeow, J. (2016). Connecting demand and supply: The role of intermediation in public procurement of innovation. Research Policy, 45(2), 414426.

[36] Fanta, B. A. (2015). Exploring the economic significance of small and medium enterprises. Journal of Governance and Regulation, 4(1), 27-34.

[37] Filser, M., De Massis, A., Gast, J., \& Kraus, S. (2018). Tracing the roots of innovativeness in family SMEs: The effect of family functionality and socioemotional wealth. Journal of Product Innovation Management, 35(4), 609-628.

[38] Fletcher, D., De Massis, A., \& Nordqvist , M. (2016). Qualitative research practices and family business scholarship: A review and future research agenda. Journal of family business strategy, 7(1), 8-25.

[39] Ghee, Y. W., Ibrahim, D. M., \& AbdulHalim, H. (2015). FAMILY BUSINESS SUCCESSION PLANNING: UNLEASHING THE KEY FACTORS OF BUSINESS PERFORMANCE. Asian Academy of Management Journal, 20(2), 1-10. 
[40] Giovannoni, E., Maraghini, P. M., \& Riccaboni, A. (2011). Transmitting knowledge across generations: The role of management accounting practices. Family Business Review, 24(2), 126-150.

[41] Gold, A. H., Malhotra, A., \& Segars, A. H. (2001). Knowledge management: an organizational capabilities perspective. Journal of Management Information Systems, 18(1), 185-214.

[42] Gomba, M., \& Kele, T. (2016). Succession planning in black-owned family businesses: a South African perspective. International Journal of Business Administration, 7(5), 9-21.

[43] Government of Punjab. (2018, 11 10). Sports Goods Industry. Sialkot, Punjab, Pakistan. Retrieved 11 10, 2018, from https://punjab.gov.pk/sialkot_key_industry

[44] Ha, T. S., Lo, C. M., \& Wang , C. Y. (2016). Relationship between knowledge management and organizational performance: a test on SMEs in Malaysia. Procedia-Social and Behavioral Sciences, 224(1), 184-189.

[45] Hair Jr, F. J., Matthews, M. L., \& Matthews, L. R. (2017). PLS-SEM or CBSEM: updated guidelines on which method to use. International Journal of Multivariate Data Analysis, 1(2), 107-123.

[46] Hair, F. J., Black, C. W., Babin, J. B., \& Anderson. (2006). Multivariate data analysis. Pearson Prentice Hall Upper Saddle River, 6(1), 1-10.

[47] Henseler, J., Ringle, M. C., \& Sinkovics, R. R. (2009). The use of partial least squares path modeling in international marketing. In New challenges to international marketing. Emerald Group Publishing Limited, 20(1), 277-319.

[48] Ho, C. T., Ahmad, H. N., \& Ramayah, T. (2016). Competitive capabilities and business performance among manufacturing SMEs: Evidence from an emerging economy, Malaysia. Journal of Asia-Pacific Business, 17(1), 37-58.

[49] Hopper, T., \& Bui, B. (2016). Has management accounting research been critical? Management Accounting Research, 31(1), 10-30.

[50] Hoque, A. S. M. M. , M. A. (2018). The effect of entrepreneurial orientation on Bangladeshi SME performance: Role of organizational culture. International Journal of Data and Network Science, 2(1), 1-14.

[51] Hosseini, H. S., Barzoki, S. A., \& Isfahani, N. A. (2018). Analysis of the effects of succession planning implementation on organisational performance. International Journal of Productivity and Quality Management, 25(2), 198-211.

[52] Ibrahim,, A., Soufani, K., Poutziouris, P., \& Lam. (2004). Qualities of an effective successor: the role of education and training. Education + Training, 9, 474-480.

[53] İpek, I. (2018). The resource-based view within the export context: An integrative review of empirical studies. Journal of Global Marketing, 31(3), 157-179.

[54] Joshi, S., \& Li, Y. (2016). What is corporate sustainability and how do firms practice it? A management accounting research perspective. Journal of Management Accounting Research, 28, 111.

[55] Karami, M., \& Tang, J. (2019). Entrepreneurial orientation and SME international performance: The mediating role of networking capability and experiential learning. International Small Business Journal, 37(2), 105-124.

[56] Kline, R. B. (2011). Principles and practice of structural equation modeling. New York: Guilford Press. Teo, T. S. H.

[57] Lansiluoto, A., Joensuu-Salo, S., \& Varamaki, V. E. (2019). suu-Salo, S., Varamäki, E., Viljamaa, A., \& Sorama, K. (2019). Market orientation and performance measurement system adoption impact on performance in SMEs. Journal of Small Business Management, 57(3), 1027-1043.

[58] Law, M., Stewart, D., Letts, L., Pollock, N., \& Bosc. (1998). Guidelines for critical review of qualitative studies. McMaster 
University occupational therapy evidencebased practice research Group, 38(3), 27981.

[59] LeCounte, F. J., Prieto, C. L., \& Phipps, T. S. (2017). CEO succession planning and organizational performance: A human capital theory approach. Journal of Leadership, Accountability and Ethics, 14(1), 46-57.

[60] Li, L., Li, D., Goerzen, A., \& Shi, S. W. (2018). What and how do SMEs gain by going international? A longitudinal investigation of financial and intellectual resource growth. Journal of World Business, 53(6), 817-834.

[61] Mao, H., Liu, S., Zhang, J., \& Deng, Z. (2016). Information technology resource, knowledge management capability, and competitive advantage: The moderating role of resource commitment. International Journal of Information Management, 36(6), 1062-1074.

[62] Maroof, Z., Hussain, S., Jawad, M., \& Naz, M. (2019). Determinants of industrial development: a panel analysis of South Asian economies. Quality \& Quantity, 53(3), 1391-1419.

[63] Mashavira, N., Chipunza, C., \& Dzansi, Y. D. (2019). Managerial interpersonal competencies and the performance of family-and non-family-owned small and medium-sized enterprises in Zimbabwe and South Africa. SA Journal of Human Resource Management, 17(1), 15-20.

[64] Masud, K. M., Nurunnabi, M., \& Bae, M. S. (2018). The effects of corporate governance on environmental sustainability reporting: Empirical evidence from South Asian countries. Asian Journal of Sustainability and Social Responsibility, 3(1), 3-5.

[65] Michel, A., \& Kammerlander, N. (2015). Trusted advisors in a family business's succession-planning process-An agency perspective. Journal of Family Business Strategy, 6(1), 45-57.

[66] Mowen, J. T., \& Visher, A. C. (2016). Changing the ties that bind: How incarceration impacts family relationships. Criminology \& Public Policy, 15(2), 503528.

[67] Mu, J., Thomas, E., Peng, G., \& Di Benedetto, A. (2017). Strategic orientation and new product development performance: The role of networking capability and networking ability. Industrial Marketing Management, 64(1), 187-201.

[68] Muriithi, M. S. (2017). African small and medium enterprises (SMEs) contributions, challenges and solutions. European Journal of Research and Reflection in Management Sciences, 5(1), 36-37.

[69] Njeri, W. L., Ngui, T., \& Mathenge, F. (2019). Succession Planning and Organizational Performance of Faith Based Organizations: A Case of Catholic Archdiocese of Nairobi. Journal of Human Resource \& Leadership, 3(3), 44-62.

[70] O'Brien, E. K., Minjock, M. R., \& Colarelli, M. S. (2018). Kinship ties and employee theft perceptions in familyowned businesses. European Management Journal, 36(3), 421-430.

[71] Oricchio , G., Lugaresi , S., Crovetto , A., \& Fontana, S. (2017). SMEs in Europe: An Overview. In: SME Funding. London: Palgrave Macmillan. doi:https://doi.org/10.1057/978-1-13758608-7_2

[72] Pearson, W. A., Carr, C. J., \& Shaw, C. J. (2008). Toward a theory of familiness: A social capital perspective. Entrepreneurship theory and practice, 32(6), 949-969.

[73] Platonova, E., Asutay, M., Dixon, R., \& Mohammad. (2018). The impact of corporate social responsibility disclosure on financial performance: Evidence from the GCC Islamic banking sector. Journal of Business Ethics, 151(2), 451-471.

[74] Proyer, T. R. (2017). A new structural model for the study of adult playfulness: Assessment and exploration of an understudied individual differences 
variable. Personality and Individual Differences, 108(1), 113-122.

[75] Quinn, M., Hiebl, R. M., Moores, K., \& Craig, B. J. (2018). Future research on management accounting and control in family firms: suggestions linked to architecture, governance, entrepreneurship and stewardship. Journal of Management Control, 28(4), 529-546.

[76] Rehman, U. A., \& Anwar, M. (2019). Mediating role of enterprise risk management practices between business strategy and SME performance. Small Enterprise Research, 26(2), 207-227.

[77] Ren, S., Eisingerich, B. A., \& Tsai, T. H. (2015). How do marketing, research and development capabilities, and degree of internationalization synergistically affect the innovation performance of small and medium-sized enterprises (SMEs)? A panel data study of Chinese SMEs. International Business Review, 24(4), 642651.

[78] Rikhardsson, P., \& Yigitbasioglu, O. (2018). Business intelligence \& analytics in management accounting research: Status and future focus. International Journal of Accounting Information Systems, 29(1), 37-58.

[79] Rodriguez-Fernandez, M. (2016). Social responsibility and financial performance: The role of good corporate governance. Business Research Quarterly, 19(2), 137151.

[80] Saan, R., Enu-Kwesi, F., \& Nyewie, R. F. (2018). Factors influencing succession planning for continuity of family-owned businesses in the Wa Municipality, Ghana. Universal Journal of Management, 6(5), 165-177.

[81] Saan, R., Enu-Kwesi, F., \& Nyewie, R. F. (2018). Factors influencing succession planning for continuity of family-owned businesses in the Wa Municipality, Ghana. Universal Journal of Management, 6(5), 165-177.

[82] Shields, J., \& Shelleman, M. J. (2016). Management accounting systems in micro-
SMEs. Journal of Applied Management and Entrepreneurship, 21(1), 19-20.

[83] Smith, M. (2019). Research methods in accounting. SAGE Publications Limited.

[84] Spriggs, M., Yu, A., Deeds, D., \& Sorenson, L. R. (2013). Too many cooks in the kitchen: Innovative capacity, collaborative network orientation, and performance in small family businesses. Family Business Review, 26(1), 32-50.

[85] Taber, S. K. (2018). The use of Cronbach's alpha when developing and reporting research instruments in science education. Research in Science Education, 48(6), 1273-1296.

[86] Too many cooks in the kitchen: Innovative capacity, collaborative network orientation, and performance in small family businesses. (2013). Family Business Review, 26(1), 32-50.

[87] Tzeng, H. G., Chiang, H. C., \& Li, W. C. (2007). Evaluating intertwined effects in elearning programs: A novel hybrid MCDM model based on factor analysis and DEMATEL. Expert systems with Applications, 32(4), 1028-1044.

[88] Uyar, M. (2019). The management accounting and the business strategy development at SMEs. Problems and perspectives in management, 17(1), 1-10.

[89] Wayland, V. S. (2019). Saving Small Business: The Urgent Need for Improved Business Succession Planning and how Immigrant Entrepreneurs can Help. Papers in Canadian Economic Development, 18(1), 57-68.

[90] Werner, A., Schröder, C., \& Chlosta, S. (2018). Driving factors of innovation in family and non-family SMEs. Small Business Economics, 50(1), 201-218.

[91] Zainal, H., Parinsi, K., Hasan, M., Said, F., \& Ak. (2018). The influence of strategic assets and market orientation to the performance of family business in Makassar City, Indonesia. Academy of Strategic Management Journal, 17(6), 1-9. 
[92] Zhang, Y., \& Qu, H. (2016). The impact of CEO succession with gender change on firm performance and successor early departure: Evidence from China's publicly listed companies in 1997-2010. Academy of Management Journal, 59(5), 1845-1868 